\title{
Tetrahydrobiopterin and the regulation of hypoxic pulmonary vasoconstriction
}

\author{
B.N. Francis, M.R. Wilkins and L. Zhao
}

ABSTRACT: Tetrahydrobiopterin $\left(\mathrm{BH}_{4}\right)$ is an essential cofactor for nitric oxide synthases (NOS). This study investigated the effect of increasing $\mathrm{BH}_{4}$ levels on hypoxia-induced pulmonary vasoconstriction (HPV).

Sprague Dawley rats and hph-1 $\left(\mathrm{BH}_{4}\right.$ deficient) mice were given $\mathrm{BH}_{4}$ before and during $\mathrm{HPV}$ in an isolated perfused lung preparation. $\mathrm{BH}_{4}$ inhibited $\mathrm{HPV}$ in a concentration-dependent manner and increased NO metabolites in the perfusate. Bradykinin-induced reductions in HPV were blunted in hph-1 mice and pre-administration of $\mathrm{BH}_{4}$ restored the response. The effect of $\mathrm{BH}_{4}$ was attenuated by L-NAME (NOS inhibitor), PTIO (NO scavenger), and catalase $\left(\mathrm{H}_{2} \mathrm{O}_{2}\right.$ catalyser) administered prior to HPV but enhanced by MnTMPyP (superoxide dismutase mimetic). The effect of $\mathrm{BH}_{4}$ on $\mathrm{HPV}$ was partially recapitulated by $\mathrm{NH}_{4}$, a stereoisomer that shares antioxidant properties with $\mathrm{BH}_{4}$ but is not a NOS cofactor.

The bioavailability of $\mathrm{BH}_{4}$ is an important determinant of the pulmonary vascular response to hypoxia. Its effects are mediated via nitric oxide, hydrogen peroxide and its antioxidant properties, and are attenuated by oxidant stress. Pharmacological administration of $\mathrm{BH}_{4}$ may have therapeutic potential in pulmonary hypertension.

KEYWORDS: Animal models, hypoxia, pulmonary vasoconstriction, pulmonary hypertension, nitric oxide, superoxide, tetrahydrobiopterin

$\mathbf{N}$ itric oxide synthases (NOS), particularly endothelial NOS (eNOS), play a major role in maintaining normal pulmonary vascular tone and structure through the production of nitric oxide (NO) from L-arginine [1-3]. Critical to NO synthesis by NOS is the bioavailability of tetrahydrobiopterin $\left(\mathrm{BH}_{4}\right)$. When $\mathrm{BH}_{4}$ is deficient through inadequate synthesis or oxidation, NOS becomes uncoupled and generates superoxide instead of NO [4].

The hph-1 mouse, generated by $N$-ethyl- $N$-nitrosourea (ENU) mutagenesis, has low tissue $\mathrm{BH}_{4}$ levels because of constitutively reduced expression of GTP cyclohydrolase-1, the rate-limiting enzyme in $\mathrm{BH}_{4}$ biosynthesis [5]. Congenital deficiency of $\mathrm{BH}_{4}$ in the hph-1 mouse leads to pulmonary hypertension, distal pulmonary vessel muscularisation and right ventricular hypertrophy $[6,7]$. The pulmonary vascular pathology in hph-1 mice is more marked than that reported in NOS-deficient mice and suggests that loss of NO production alone is not the sole reason for the vascular pathology [1, 8]. In addition to reduced $\mathrm{NO}$ synthesis, and consistent with uncoupling of NOS, biochemical analysis of tissue homogenates from hph-1 mice shows increased local pulmonary vascular superoxide production [7]. Vascular superoxide production has a number of important actions on vascular tissue, such as scavenging of $\mathrm{NO}$, peroxynitrite formation and modulation of redox-sensitive signalling pathways [9], which may adversely affect vascular structure.

There is increasing evidence of oxidative stress in pulmonary hypertension [10, 11], including reports of nitrotyrosine formation (a marker of peroxynitrite production) in the lungs of patients with the disease [12]. Superoxide and peroxynitrite oxidise $\mathrm{BH}_{4}$, and enhanced oxidative degradation is thought to be a major cause of reduced $\mathrm{BH}_{4}$ bioavailability and eNOS uncoupling in endothelial dysfunction states [13-15]. As a result, there is interest in using exogenous $\mathrm{BH}_{4}$ therapeutically in pulmonary hypertension to restore tissue levels and promote NO production from NOS. Recent studies suggest that $\mathrm{BH}_{4}$ may also act independently of $\mathrm{NO}$, generating hydrogen peroxide, another molecule with vasorelaxant properties [16, 17].
AFFILIATIONS

Experimental Medicine and

Toxicology, Imperial College London, Hammersmith Hospital, London, UK.

CORRESPONDENCE

L. Zhao

Experimental Medicine and

Toxicology, Imperial College London Hammersmith Hospital

Ducane Road

London

W12 ONN

UK

E-mail: I.zhao@imperial.ac.uk

Received:

Nov 262009

Accepted after revision:

Feb 282010

First published online:

March 112010 
The purpose of this study was to investigate the pharmacological effects of $\mathrm{BH}_{4}$ on pulmonary vascular tone, specifically hypoxiainduced vasoconstriction (HPV) in an in situ isolated perfused lung preparation. Employing the $\mathrm{BH}_{4}$ deficient hph-1 mouse, we explored further the underlying mechanism of $\mathrm{BH}_{4}$ in balancing $\mathrm{NO}$ and superoxide production in pulmonary vasculature.

\section{METHODS}

\section{Animals}

Male Sprague-Dawley rats (250-360 g) from Charles River (Margate, UK) and hph-1 mice aged 3-5 months generated by ENU mutagenesis were used for experiments. Wild-type (WT) animals, hph-1 heterozygous (+/-) and hph-1 homozygous (hph-1) littermates on a C57BL/6 background were obtained by interbreeding hph-1 heterozygotes [5]. All studies were conducted in accordance with UK Home Office Animals (Scientific Procedures) Act 1986.

\section{Reagents}

$6 \mathrm{R}^{-\mathrm{BH}_{4}}$ (sapropterin dihydochloride or $\mathrm{BH}_{4}$ ) was supplied by BioMarin Pharmaceuticals, Inc. (Novato, CA, USA). U46619 (9, 11-dideoxy-11 $\alpha, 9 \alpha$-epoxymethanoprostaglandin $\mathrm{F}_{2 \alpha}$ ), L-NAME ( $N_{\omega}$-nitro-L-arginine methyl ester hydrochloride), Catalase, MnTMPyP (Mn(III) tetrakis(1-methyl-4-pyridyl) porphyrin pentachloride), PTIO (2-phenyl-4,4,5,5-tetramethylimidazoline-1oxyl 3-oxide), bradykinin (BK) and chemical components of the perfused solutions were obtained from Sigma-Aldrich (Poole, UK). $\mathrm{NH}_{4}$ (6R, S-5,6,7,8-tetrahydro-D-neopterin) was from Schircks Laboratories (Jona, Switzerland). All drugs were prepared fresh every day before experiments. $10 \mu \mathrm{g} \cdot \mathrm{uL}^{-1} \mathrm{BH}_{4}$ or $\mathrm{NH}_{4}$ were dissolved in HEPES buffered saline (composition: $\mathrm{NaCl} 137$ mM, KCl 4.0 mM, $\mathrm{CaCl}_{2} 1.8$ mM, MgCl 21 mM, HEPES $10 \mathrm{mM}$, glucose $10 \mathrm{mM}$; pH adjusted to 7.4 with $\mathrm{NaOH}$ ).

\section{Isolated perfused rat lung preparation}

The pulmonary vascular response to $\mathrm{BH}_{4}$ was studied using the isolated rat lung preparation previously described [18]. Briefly rats were anaesthetised with Hypnorm (fentany-fluanisone). The lungs were left in situ after the trachea had been cannulated, ventilated with air $\left(21 \% \mathrm{O}_{2}, 5 \% \mathrm{CO}_{2}\right.$ balanced $\left.\mathrm{N}_{2}\right)$ at constant end expiration pressure of $4 \mathrm{mmHg}$ with 60 breaths $\cdot \mathrm{min}^{-1}$; and perfused with a mixture (1:1) of DMEM (Dubelcco's Modified Eagles Medium) with 4\% Ficoll, and blood withdrawn from the experimental animal $(\mathrm{pH} 7.4)$ at a flow rate of $18 \mathrm{~mL} \cdot \mathrm{min}^{-1}$ using a non-pulsatile pump (Masterflex model 7519; Cole-Parmer Instrument Co. Ltd, London, UK). Pulmonary artery pressure ( $P$ pa) was measured using a pressure transducer connected to PowerLab Data Acquisition system (ADInstruments Limited, Chalgrove, UK). $\mathrm{HPV}$ was produced by ventilating the lung with $2 \% \mathrm{O}_{2}, 5 \% \mathrm{CO}_{2}$ and $93 \% \mathrm{~N}_{2}$ for $15 \mathrm{~min}$. The ventilation was then returned to air for $10 \mathrm{~min}$ to resume the PAP baseline before the next hypoxic challenge. Successive hypoxic challenges (usually 3) were repeated until the HPV response was consistent before vehicle or $\mathrm{BH}_{4}$ treatment was given to examine the effect on HPV.

\section{$\mathrm{BH}_{4}$}

$\mathrm{BH}_{4}$ (final perfusate concentration $0.3 \mu \mathrm{g} \cdot \mathrm{mL}^{-1}$ ) was added to the perfusate $\sim 4 \mathrm{~min}$ before the hypoxic challenge. Once the pressor response had returned to baseline, the hypoxic challenge was repeated with or without a second aliquot of
$\mathrm{BH}_{4}$ (calculated to produce perfusate concentrations of 0.3 or $1 \mu \mathrm{g} \cdot \mathrm{mL}^{-1}$ ) added to the perfusate (fig. 1). Perfusate samples $(100 \mu \mathrm{L})$ were collected after passage through the lungs $1 \mathrm{~min}$ prior to and $4 \mathrm{~min}$ after $\mathrm{BH}_{4}$ administration and before the hypoxic challenge for measurement of nitrate/nitrite $\left(\mathrm{NO}_{\mathrm{x}}\right)$ concentration. The effect of $\mathrm{BH}_{4}$ was calculated as the per cent change in HPV response and $\mathrm{NO}_{x}$ levels after $\mathrm{BH}_{4}$ administration compared to the HPV response and $\mathrm{NO}_{\mathrm{x}}$ levels before $\mathrm{BH}_{4}$ administration in the same animal.

\section{Isolated perfused mouse lung preparation}

Animals were anaesthetised and the lungs ventilated with air (volume controlled ventilation, $230 \mu \mathrm{L}$ tidal volume, 80 breaths. $\min ^{-1}$ and $2 \mathrm{cmH}_{2} \mathrm{O}$ positive end-expiratory pressure) via the trachea. The lungs were perfused through the main pulmonary artery accessed via the right ventricle and perfusate collected from the left atrium for recycling in a closed circuit (type 839; Hugo Sachs Electronik-Harvard Apparatus $\mathrm{GmbH}$, MarchHuggstetten, Germany). Using a nonperistaltic pump, the perfusate (DMEM with $4 \%$ Ficol, HEPES-buffered, pH 7.4) was delivered at an initial flow of $0.2 \mathrm{~mL} \cdot \mathrm{min}^{-1}$, increasing in increments after $10 \mathrm{~min}$ to $2 \mathrm{~mL} \cdot \mathrm{min}^{-1}$. The reservoir volume was set at $10 \mathrm{~mL}$ and $\mathrm{pH}$ monitored by the $\mathrm{pH}$ sensor placed in the reservoir. $P$ pa was measured using a pressure transducer connected to the inflow catheter. Left atrial pressure was


FIGURE 1. a) Representative pulmonary arterial pressure (Ppa) trace illustrating the protocol for tetrahydrobiopterin $\left(\mathrm{BH}_{4}\right)$ administration prior to induction of hypoxia-induced pulmonary vasoconstriction (HPV) in the rat isolated perfused lung. b) The effect of $\mathrm{BH}_{4}$ on HPV response (reduction expressed as a percentage of $\mathrm{HPV}$ before $\mathrm{BH}_{4}$ administration in the same animal, $\square$ ) and percentage increase in perfusate $\mathrm{NO}_{x}$ levels $(\boldsymbol{\square})$ following $\mathrm{BH}_{4}$ administration $(\mathrm{n}=5)$. 
measured using a pressure transducer connected to the outflow catheter. Pressure tracings were collected and analysed using PowerLab Data Acquisition system. U46619 (thromboxane analogue; $5 \mu \mathrm{M}$ ) was added to reservoir to induce basal pulmonary vasoconstriction. 2 min after U46619 administration, a stable $P$ pa was achieved and recording was continued for a further $6 \mathrm{~min}$ before HPV was induced by ventilating the lung with $2 \% \mathrm{O}_{2}, 5 \% \mathrm{CO}_{2}$ and $93 \% \mathrm{~N}_{2}$. Ventilation was returned to air until $P$ pa returned to baseline (fig. 2a).

$\mathrm{BH}_{4}$ and $\mathrm{NH}_{4}$

Vehicle (fig. 2a), $\mathrm{BH}_{4}\left(1,10\right.$ and $100 \mu \mathrm{g} \cdot \mathrm{mL}^{-1}$; fig. 2b) or $\mathrm{NH}_{4}$ $\left(100 \mu \mathrm{g} \cdot \mathrm{mL}^{-1}\right)$ was added to the perfusate during stable HPV. The effect of $\mathrm{BH}_{4}$ and $\mathrm{NH}_{4}$ was calculated as the $P$ pa reduction $(\triangle P$ pa $3 \mathrm{~min}$ after drug administration expressed as a percentage of the maximum $\mathrm{HPV}$ response $\left(\mathrm{HPV}_{\max }\right)$ in the same hypoxia challenge.

\section{Bradykinin}

BK $\left(10 \mathrm{ng} \cdot \mathrm{mL}^{-1}\right)$ was administered during stable HPV in WT, +/- and hph-1 mice (fig. 3). Futhermore, in separate sets of hph-1 mice, $\mathrm{BH}_{4}\left(100 \mu \mathrm{g} \cdot \mathrm{mL}^{-1}\right)$ was added to reservoir $3 \mathrm{~min}$ before $10 \mathrm{ng} \cdot \mathrm{mL}^{-1}$ of BK. The response to BK was calculated as the maximum reduction in $P$ pa (usually within $1 \mathrm{~min}$ of $\mathrm{BK}$ administration) expressed as a percentage of the $\mathrm{HPV}_{\max }$ in the same hypoxia challenge.

\section{Inhibition of NO and superoxide}

In separate experiments, L-NAME $(100 \mu \mathrm{M})$, catalase $\left(200 \mathrm{U} \cdot \mathrm{mL}^{-1}\right)$, MnTMPyP $(1 \mu \mathrm{M})$ and PTIO $(1 \mu \mathrm{M})$ was added to the perfusate $3 \mathrm{~min}$ before inducing $\mathrm{HPV}$, followed by $\mathrm{BH}_{4}$ $\left(100 \mu \mathrm{g} \cdot \mathrm{mL}^{-1}\right)$ administration during stable $\mathrm{HPV}$ (fig. 4). $\mathrm{BH}_{4}$ effect was calculated as $P$ pa reduction $(\triangle P$ pa $) 3$ min after $\mathrm{BH}_{4}$ administration expressed as a percentage of the $\mathrm{HPV}_{\max }$ in the same hypoxia challenge.

\section{Measurements of nitrate/nitrite $\left(\mathrm{NO}_{\mathrm{x}}\right)$}

Perfusate samples were centrifuged at $1000 \times g$ for $4 \mathrm{~min}$. The supernatant was immediately removed and stored at $-20^{\circ} \mathrm{C}$ until analysis. $\mathrm{NO}_{x}$ concentration was measured in duplicate using an ozone-based chemiluminescence method [19]. Briefly, prior to analysis the samples were treated with a 1:1 volume of cold ethanol and centrifuged at 14,000 $\times g$ for $5 \mathrm{~min}$. $\mathrm{NO}_{\mathrm{x}}$ levels were measured by injecting $50 \mu \mathrm{L}$ of the supernatant in a glass purge vessel containing vanadium(III) in $1 \mathrm{~N}$ hydrochloric acid at $90^{\circ} \mathrm{C}$, which reduced $\mathrm{NO}_{x}$ to $\mathrm{NO}$ gas. A nitrogen stream was bubbled through the purge vessel containing vanadium(III), first through $1 \mathrm{~N} \mathrm{NaOH}$, and then into a $\mathrm{NO}$ analyser (Sievers Model $280 \mathrm{NO}$ Analyser; Sievers Instruments, Boulder, $\mathrm{CO}$, USA), which detected $\mathrm{NO}$ released from $\mathrm{NO}_{x}$ by chemiluminescent detection. Results are presented as the percentage of the $\mathrm{NO}_{x}$ levels after $\mathrm{BH}_{4}$ administration in the perfusate compared with the levels prior to administration.

\section{Statistical analysis}

In all experiments, results are expressed as mean \pm SEM; $n$ equals the number of mice or rats per experiment. Statistical analysis of the data was performed by using unpaired t-test when appropriate, nonparametric test with Man-Whitney modification, or one-way ANOVA when applied to multiple group comparisons. A value of $p<0.05$ was considered statistically significant.
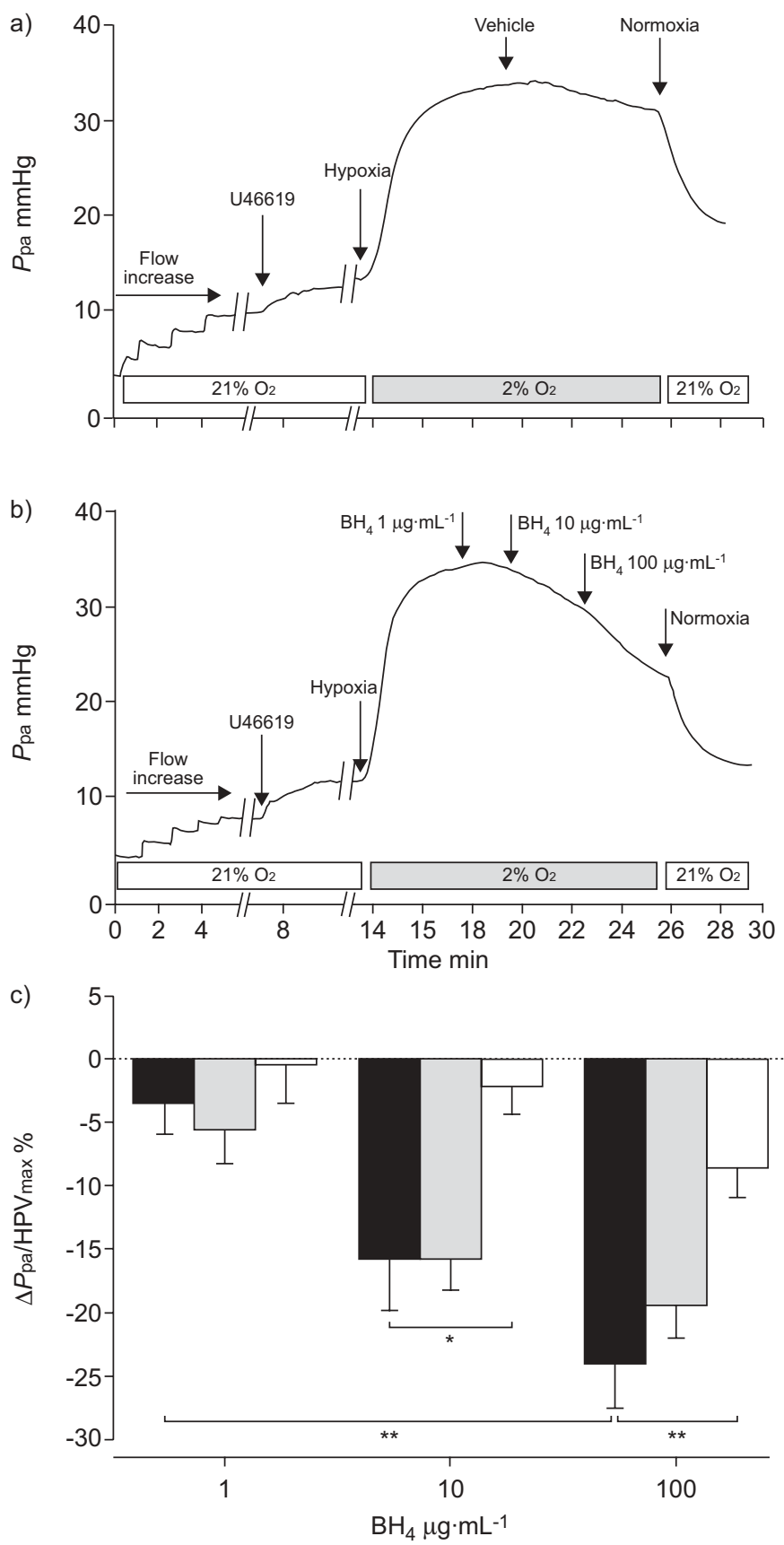

FIGURE 2. Representative traces demonstrating the protocol in isolated mouse lung and showing the effects of a) vehicle and b) tetrahydrobiopterin $\left(\mathrm{BH}_{4}\right)$ administration on pulmonary arterial pressure $(P p a)$ during hypoxic pulmonary vasoconstriction (HPV) in wild-type (WT) mice. c) Vasorelaxant effect of $\mathrm{BH}_{4}$ administration (1, 10 and $100 \mu \mathrm{g} \cdot \mathrm{mL}^{-1}$ perfusate) on Ppa during HPV in WT (ש) heterozygous $(\square)$ and hph-1 $(\square)$ mice. The effect of $\mathrm{BH}_{4}$ was calculated as $P$ pa reduction ( $\triangle \mathrm{Ppa}$ ) 3 min after $\mathrm{BH}_{4}$ administration expressed as a \% of the maximum HPV response $\left(H P V_{\text {max }}\right)$ in the same hypoxia challenge. ${ }^{*}: p<0.05$; ${ }^{*}: p<0.01 . n=3-9$.

\section{RESULTS}

$\mathrm{BH}_{4}$ attenuates $\mathrm{HPV}$ in the isolated perfused rat lung

The effect of increasing concentration of $\mathrm{BH}_{4}$ on HPV and $\mathrm{NO}_{x}$ levels was first examined in the isolated perfused rat lung. 


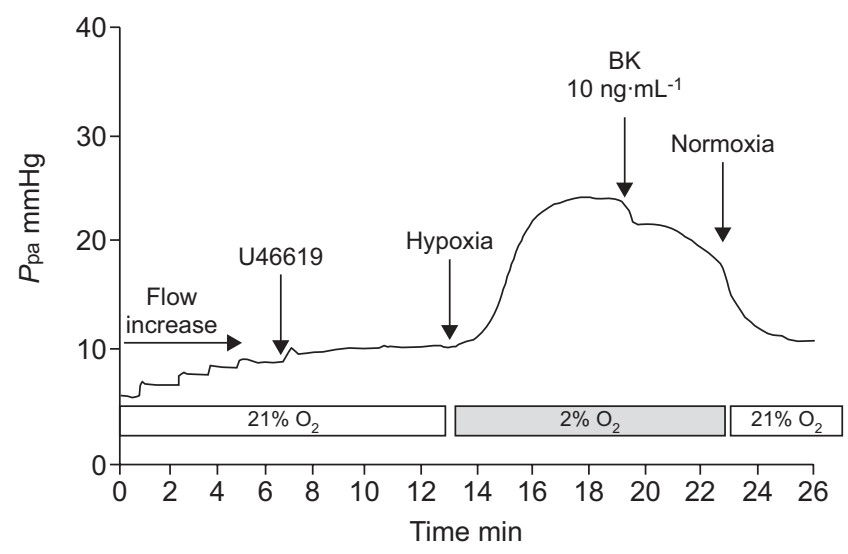

FIGURE 3. Representative trace of bradykinin (BK) effect on pulmonary artery pressure $(\mathrm{Ppa})$ during hypoxic pulmonary vasoconstriction (HPV) in the isolated perfused mouse lung. BK administration induces an abrupt reduction followed by a gradual decline in Ppa. The effect of BK was calculated as the reduction (at $1 \mathrm{~min}$ ) in $P$ pa expressed as a percentage of the maximum HPV response in the same hypoxia challenge.

Consistent HPV responses were established $(11.6 \pm 2.8 \mathrm{mmHg}$, $\mathrm{n}=15$ ) in each lung preparation before exposure to exogenous $\mathrm{BH}_{4} \cdot \mathrm{BH}_{4}$ at $1 \mu \mathrm{g} \cdot \mathrm{mL}^{-1}$, but not $0.3 \mu \mathrm{g} \cdot \mathrm{mL}^{-1}$, attenuated the pressor response to hypoxia $(-31.9 \%$, HPV $8.5 \pm 2.7 \mathrm{mmHg}$ versus $12.4 \pm 2.8 \mathrm{mmHg}$ with or without $\mathrm{BH}_{4} 1 \mu \mathrm{g} \cdot \mathrm{mL}^{-1}$, respectively; $\mathrm{p}<0.01, \mathrm{n}=5$; fig. 1). Perfusate $\mathrm{NO}_{x}$ levels were increased at both $\mathrm{BH}_{4}$ concentrations $(27 \pm 6 \%$ and $47 \pm 15 \%$, respectively; fig. $1 b$ ).

\section{$\mathrm{BH}_{4}$ attenuates $\mathrm{HPV}$ in the isolated perfused mouse lung}

To explore the effect of restoring $\mathrm{BH}_{4}$ in the context of impaired endogenous synthesis of the cofactor, studies were conducted in WT, hph-1 heterozygous (+/-) and hph-1 homozygous (hph-1) mice. Hypoxia induced similar maximum rises in $P$ pa in each of the mouse genotypes: $17.1 \pm 1.3 \mathrm{mmHg}$ in WT, $14.7 \pm 1.1 \mathrm{mmHg}$ in heterozygous and $16.1 \pm 1.0 \mathrm{mmHg}$ in hph-1 $(\mathrm{n}=12-15)$. Compared to vehicle (fig. 2a), $\mathrm{BH}_{4} 1,10$ and $100 \mu \mathrm{g} \cdot \mathrm{mL}^{-1}$ administered during stable HPV induced concentrationdependent reductions in $P$ pa (fig. 2b). Data from all three genotypes are summarised in figure $2 \mathrm{c}$. $\mathrm{BH}_{4}$ produced greater falls in WT than in hph-1 mice at doses of 10 and $100 \mu \mathrm{g} \cdot \mathrm{mL}^{-1}$ (fig. 2c).

\section{$\mathrm{BH}_{4}$ restores the response to $\mathrm{BK}$ in $\mathrm{hph}-1$ mouse}

In order to examine endothelial function in hph-1 mice, the vasorelaxant response to BK was investigated in the isolated perfused lung (fig. 3). BK administration to achieve a perfusate concentration of $10 \mathrm{ng} \cdot \mathrm{mL}^{-1}$ during stable HPV reduced $P_{\mathrm{pa}}$ in WT $(-12.1 \pm 1.8 \%)$ and heterozygous $(-9.7 \pm 1.2 \%)$ mice, but had no detectable effect in hph-1 mice $(0 \pm 1.7 \%)$ (table 1$)$. $\mathrm{BH}_{4}$ $\left(100 \mu \mathrm{g} \cdot \mathrm{mL}^{-1}\right)$ given prior to BK restored the response to BK in hph-1 mice $(-11.7 \pm 2.4 \%)$.

\section{The effect of L-NAME, catalase, MnTMPYP and PTIO on the} response to $\mathrm{BH}_{4}$ in mice

To further dissect the mechanism by which $\mathrm{BH}_{4}$ regulates pulmonary vascular tone, the roles of $\mathrm{NO}$ and reactive oxygen species were investigated. In this set of experiments, the maximum HPV response before treatment was in the range of
$8-10 \mathrm{mmHg}$ in all the three genotypes (see initial HPV, table 2). L-NAME, catalase, MnTMPyP and PTIO had minor effects on the baseline normoxic $P$ pa $(-0.5$ to $1.1 \pm 0.5 \mathrm{mmHg})$ and these were similar among the three genotypes (see table 1 , online supplementary material).

L-NAME and $\mathrm{BH}_{4}$

NOS inhibitor L-NAME $(100 \mu \mathrm{M})$ administration enhanced the HPV response in all three genotypes (table 2), and reduced the effect of $\mathrm{BH}_{4}\left(100 \mu \mathrm{g} \cdot \mathrm{mL}^{-1}\right)$ in WT $(-20 \pm 3 \%$ versus $-11 \pm 1.7 \%$, in the absence and presence of L-NAME, respectively; $\mathrm{p}<0.05$; fig. $4 \mathrm{a}$ ).

Catalase and $\mathrm{BH}_{4}$

Pretreatment with catalase increased the HPV response significantly in heterozygous and hph-1 mice, but not in WT mice (table 2). It attenuated the effect of $\mathrm{BH}_{4}$ in WT mice significantly $(-20 \pm 3 \%$ versus $-7.8 \pm 2 \%$; $p<0.01$; fig. $4 \mathrm{~b})$, and to a lesser degree in heterozygous and hph-1 mice.

\section{MnTMPyP and $\mathrm{BH}_{4}$}

The intracellular superoxide dismutase mimetic MnTMPyP did not affect HPV (table 2). It enhanced the vasodepressor effect of $\mathrm{BH}_{4}$ significantly in all the genotypes and almost returned $P$ pa to baseline levels. The net change was greater in hph-1 animals $(-32.5 \pm 3 \%$ versus $-7.9 \pm 2.9 \%$, in the presence and absence of MnTMPyP, respectively; $\mathrm{p}<0.01$ ) than in WT mice $(-34.8 \pm 2.8 \%$ with MnTMPyP versus $-20 \pm 3 \%$ without; $\mathrm{p}<0.01$; fig. 4c).

PTIO and $\mathrm{BH}_{4}$

Pretreatment with an NO scavenger, PTIO, increased HPV significantly in WT mice (table 2) and attenuated the subsequent $\mathrm{BH}_{4}$-induced reduction in $P_{\mathrm{pa}}(-20.5 \pm 3 \%$ versus $-7.3 \pm 0.9 \%$; $<<0.01$; fig. $4 \mathrm{~d}$ ).

\section{The effect of $\mathrm{NH}_{4}$ on HPV response}

To evaluate the antioxidant action of $\mathrm{BH}_{4}$, its stereoisomer $\mathrm{NH}_{4}$ was used for comparison in the isolated perfused lung WT mouse lung. $\mathrm{NH}_{4} 100 \mu \mathrm{g} \cdot \mathrm{mL}^{-1}$ produced a smaller fall in $P$ pa $(-6.4 \pm 2.3 \%)$ than $\mathrm{BH}_{4} 100 \mu \mathrm{g} \cdot \mathrm{mL}^{-1}(-31 \%$; $<<0.01$; fig. 4 e).

\section{DISCUSSION}

In the present study, exogenous $\mathrm{BH}_{4}$ attenuated the acute pulmonary vascular pressor response to hypoxia in a concentration-dependent manner. There appear to be three mediators of the effect: increased NO production, a direct antioxidant action and $\mathrm{H}_{2} \mathrm{O}_{2}$. Evidence that the response to $\mathrm{BH}_{4}$ is mediated in part by coupling NOS to increase NO production and improve pulmonary endothelial function comes from: 1 ) the associated increase in $\mathrm{NO}\left(\mathrm{NO}_{\mathrm{x}}\right.$ levels) in the perfusate; 2) the observation that $\mathrm{BH}_{4}$ restored the response to $\mathrm{BK}$, an endothelium-dependent vasodilator, in the hph-1 mouse; and 3) that the effect was inhibited by pretreatment of L-NAME, a NOS inhibitor, and PTIO, a NO scavenger. A direct antioxidant effect from $\mathrm{BH}_{4}$ is inferred from the response to $\mathrm{NH}_{4}$, a $\mathrm{BH}_{4}$ stereoisomer that has antioxidant properties but which is not a NOS cofactor. A role for $\mathrm{H}_{2} \mathrm{O}_{2}$ is supported by the observation that catalase, which promotes the decomposition of $\mathrm{H}_{2} \mathrm{O}_{2}$ to oxygen and water, attenuated the vasorelaxant effect of $\mathrm{BH}_{4}$. Conversely, the effect of $\mathrm{BH}_{4}$ is reduced by increased superoxide production, as seen in the hph-1 mouse. 



FIGURE 4. The vasorelaxant effect of tetrahydrobiopterin $\left(\mathrm{BH}_{4}\right)$ on pulmonary artery pressure (Ppa) during hypoxic pulmonary vasoconstriction ( $\mathrm{HPV}$ ) in the isolated perfused mouse lung administered before and after a) L-NAME $\left(N_{\omega}\right.$-nitro-L-arginine methyl ester hydrochloride; $\left.\left.100 \mu M ; n=3-10\right), b\right) c$ catalase $\left(200 \quad U \cdot \mathrm{mL}^{-1} ; \mathrm{n}=3-10\right)$ and c) MnTMPyP (Mn(III) tetrakis(1-methyl-4-pyridyl) porphyrin pentachloride; $1 \mu \mathrm{M} ; \mathrm{n}=3-10$ ) in wild-type (WT; $\square$ ), heterozygous ( $\square$ ) and hph-1 ( $\square$ ) mice, and d) PTIO (2phenyl-4,4,5,5-tetramethylimidazoline-1-oxyl 3-oxide; $10 \mu \mathrm{M}, \mathrm{n}=4-7)$ in WT mice. *: $\mathrm{p}<0.05$; **: $\mathrm{p}<0.01$. The effect of $\mathrm{BH}_{4}$ is calculated as the $P$ pa reduction $(\Delta P \mathrm{pa}) 3 \mathrm{~min}$ after $\mathrm{BH}_{4}$ administration expressed as a percentage of the maximum HPV response ( $\mathrm{HPV}$ max) in the same hypoxia challenge. e) The effect of $\mathrm{BH}_{4}$ and $\mathrm{NH}_{4}(6 \mathrm{R}, \mathrm{S}-5,6,7,8-$ tetrahydro-D-neopterin; $100 \mu \mathrm{g} \cdot \mathrm{mL}^{-1}$ ) on Ppa administered during HPV in WT mice. *: $\mathrm{p}<0.05$ compared with $\mathrm{BH}_{4}$ effect ( $\mathrm{n}=3-7$ each group).

Prior treatment with MnTMPyP, an intracellular superoxide dismutase mimetic, restored the response to $\mathrm{BH}_{4}$ in hph-1 mice and reversed HPV to near baseline Ppa levels.

HPV is a characteristic of the pulmonary circulation, in which resistance vessels constrict in response to alveolar hypoxia in order to maintain perfusion/ventilation matching [20]. NO synthesis contributes to this vasoregulatory mechanism [21]. For example, reduced NO bioavailability through inhibition of NOS with L-NAME or NO scavenging with PTIO augments HPV. Conversely, increased NO synthesis attenuates HPV. Attenuation of $\mathrm{HPV}$ with $\mathrm{BH}_{4}$ in the isolated perfused rat lung is consistent with the known biochemistry of $\mathrm{BH}_{4}$ as an essential cofactor for NOS dimerisation, stability and electron transfer during arginine oxidation [22]. Interestingly, in a previous experiment we showed that hph-1 mice, which are relatively deficient in $\mathrm{BH}_{4}$, were more sensitive to hypoxia [7]. In this study, we sought to maximally stress the pulmonary vasculature with the vasoconstrictor $\mathrm{U} 46619$ as well as hypoxia, and achieved similar maximal responses to HPV in all three genotypes (WT, and heterozygous and homozygous hph-1 mice).

L-NAME and PTIO, at doses described previously to cause full inhibition of the NO system [23, 24], only partially blocked the effects of $\mathrm{BH}_{4}$ on $P$ pa during the stable phase of HPV in WT mice, indicating that "NOS coupling" is not the sole mechanism by which $\mathrm{BH}_{4}$ modulates HPV. In addition to uncoupled NOS, the generation of superoxide and free radicals from NADPH oxidase and the mitochondrial electron transport system has been implicated in HPV. $\mathrm{BH}_{4}$ is a potent reducing agent [25] and has been shown to prevent ischaemia reperfusion injury through its antioxidant properties rather than acting as a NOS cofactor [26]. To address this contribution to its effect on HPV, we examined the effect of $\mathrm{NH}_{4}$, an equipotent antioxidant analogue of $\mathrm{BH}_{4}$ with no cofactor activity. At the same 


\begin{tabular}{|c|c|c|}
\hline & $\triangle P$ pa $\mathrm{mmHg}$ (HPV response) &  \\
\hline WT & $17.8 \pm 2.3$ & $12.1 \pm 1.8$ \\
\hline Heterozygous & $15.6 \pm 0.6$ & $9.7 \pm 1.2$ \\
\hline Hph-1 without $\mathrm{BH}_{4}$ & $15.8 \pm 0.8$ & $0.0 \pm 1.7$ \\
\hline
\end{tabular}

\#: $\mathrm{n}=3-4$ each group. The effect of BK $\left(10 \mathrm{ng} \cdot \mathrm{mL}^{-1}\right)$ on HPV in hph-1 mice was measured before and after tetrahydrobiopterin $\left(\mathrm{BH}_{4}\right)\left(100 \mu \mathrm{g} \cdot \mathrm{mL}^{-1}\right)$. The maximum HPV response (initial $\triangle P p a$ ) was not significantly different among the three genotypes.

concentration, the reduction in $P$ pa produced by $\mathrm{NH}_{4}$ was $\sim 30 \%$ of that produced by $\mathrm{BH}_{4}$. Whether the antioxidant effect of $\mathrm{BH}_{4}$ is related mainly to reduction of superoxide or the nitrosyl radical (peroxynitrite), and how these reactions might influence the total effect of $\mathrm{BH}_{4}$ on pulmonary pressure, is unknown and needs further investigation.

$\mathrm{H}_{2} \mathrm{O}_{2}$ is also a mediator of the effect of $\mathrm{BH}_{4}$ on $P$ pa. The NOS family is a major source of vascular $\mathrm{H}_{2} \mathrm{O}_{2}$, derived from superoxide by the action of various superoxide dismutases. $\mathrm{H}_{2} \mathrm{O}_{2}$ has been proposed to be an endothelium-derived hyperpolarising factor (EDHF). Recent data suggest that $\mathrm{H}_{2} \mathrm{O}_{2}$ may be an important regulator of vascular homeostasis in small vessels [27]. EDHF-mediated relaxation and hyperpolarisation of mesenteric arteries in response to acetylcholine is reduced progressively in eNOS, $\mathrm{n} / \mathrm{eNOS}$, and $\mathrm{n} / \mathrm{i} / \mathrm{eNOS}$ deficient mice as the number of disrupted NOS genes increases [27]. The vascular effects of $\mathrm{H}_{2} \mathrm{O}_{2}$ are unmasked by $\mathrm{BH}_{4}$ deficiency, where superoxide production is increased and NO synthesis reduced [7]. Catalase inhibits endotheliumdependent relaxation in the aorta of hph-1, but not WT mice [28] and significantly augmented HPV in heterozygous and hph-1, but not in WT mice in our study.

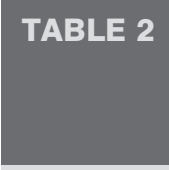
Effect of inhibiting nitric oxide, superoxide and hydrogen peroxide bioavailability on hypoxic pulmonary vasoconstriction (HPV) in isolated perfused mouse lung

\begin{tabular}{lrrc} 
Experimental protocol & \multicolumn{3}{c}{$\Delta P$ pa $\mathbf{m m H g}$ (HPV response) } \\
\cline { 2 - 4 } & \multicolumn{1}{c}{$\mathbf{W T}$} & Heterozygous & Hph-1 \\
\hline Maximum HPV & $7.2 \pm 2.1$ & $8.0 \pm 2.1$ & $7.5 \pm 0.9$ \\
HPV + L-NAME (100 $\boldsymbol{\mu M})$ & $13.4 \pm 4.2^{\#}$ & $11.1 \pm 0.9^{\bullet}$ & $12.8 \pm 0.7^{*}$ \\
HPV + PTIO (10 $\boldsymbol{\mu M})$ & $9.8 \pm 0.7^{\#}$ & & \\
HPV + catalase $\left(\mathbf{2 0 0} \mathbf{U} \cdot \mathbf{m L}^{-1}\right)$ & $10.3 \pm 2.4$ & $10.7 \pm 3.2^{\bullet}$ & $11.7 \pm 3.1^{*}$ \\
HPV + MnTMPyP $(\mathbf{1} \boldsymbol{\mu M})$ & $9.1 \pm 1.8$ & $9.1 \pm 2.1$ & $8.8 \pm 0.5$ \\
\hline
\end{tabular}

$\triangle P$ pa: reduction in pulmonary arterial pressure; WT: wild type; L-NAME: $N_{\omega}$-nitroL-arginine methyl ester hydrochloride; PTIO: 2-phenyl-4,4,5,5tetramethylimidazoline-1-oxyl 3-oxide; MnTMPyP: Mn(III) tetrakis(1-methyl-4pyridyl) porphyrin pentachloride; $\#: p<0.05$ compared with WT controls; $\because \mathrm{p}<0.05$ compared with heterozygous controls; *: $p<0.05$ compared with hph-1 controls.
Paradoxically, increasing $\mathrm{BH}_{4}$ levels also increases $\mathrm{H}_{2} \mathrm{O}_{2}$. It is now accepted that the NOS family produce superoxide under normal conditions, not just when uncoupled. $\mathrm{BH}_{4}$ enables both superoxide and NO production from NOS and increases $\mathrm{H}_{2} \mathrm{O}_{2}$ production [24]. It may also generate $\mathrm{H}_{2} \mathrm{O}_{2}$ directly following oxidation by molecular oxygen in aqueous solution [17]. Catalase inhibited $\mathrm{BH}_{4}$ induced vasorelaxation in mouse cerebral arteries [24] and rabbit iliac arteries, and inhibited the vasodilatory effect of $\mathrm{BH}_{4}$ on HPV in WT mice in our study. The mechanism by which $\mathrm{H}_{2} \mathrm{O}_{2}$ produces its vasorelaxant effects includes activation of soluble guanylate cyclase [29], stimulating the production of prostanoids [30] and sarcoplasmic endoplasmic reticulum $\mathrm{Ca}^{2+}$ ATPase [16].

Conversely, oxidation of $\mathrm{BH}_{4}$ limits its bioavailability and so efficacy. Peroxynitrite, the product of superoxide and NO, oxidises $\mathrm{BH}_{4}$ to $\mathrm{BH}_{2}$ with 10 times greater potency than it reacts with other cellular oxidants, such as ascorbic acid and

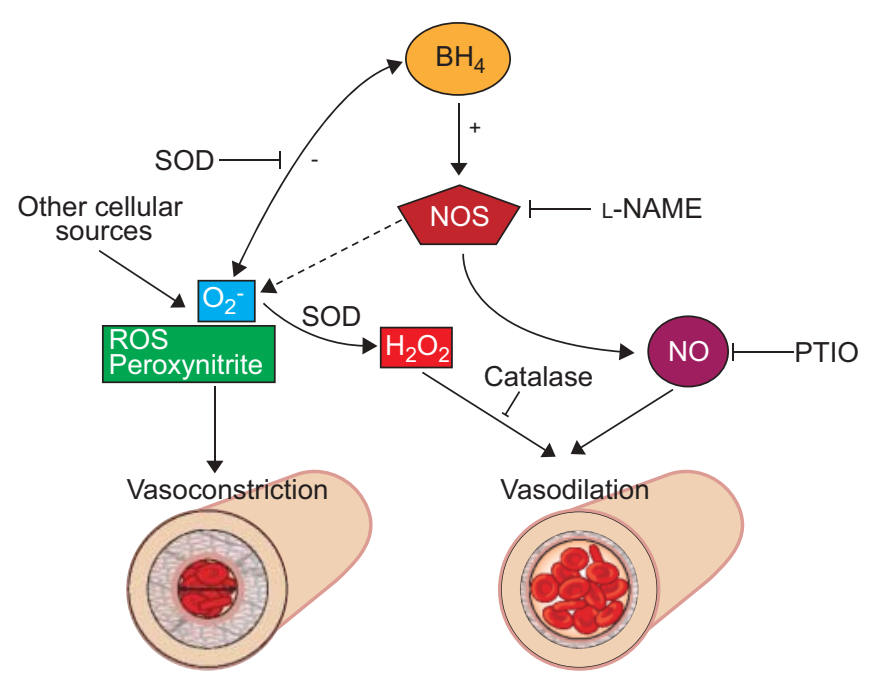

FIGURE 5. Schematic representation of the proposed mechanisms by which tetrahydrobiopterin $\left(\mathrm{BH}_{4}\right)$ regulates pulmonary vascular tone. $\mathrm{BH}_{4}$ mediates its effects via nitric oxide synthase (NOS) coupling to balance the generation of nitric oxide and superoxide, and consequently the formation of hydrogen peroxide and peroxynitrite. $\mathrm{BH}_{4}$ also has antioxidant activity. The effect of $\mathrm{BH}_{4}$ is attenuated in the presence of oxidative stress and antioxidant agents, such as superoxide dismutase (SOD), augment its efficacy. The overall net effect of $\mathrm{BH}_{4}$ is vasorelaxation. L-NAME: $N_{\omega}$-nitro-arginine methyl ester hydrochloride; ROS: reactive oxygen species; PTIO 2-phenyl-4,4,5,5-tetramethylimidazoline-1-oxyl 3-oxide. 
glutathione [31]. Oxidised $\mathrm{BH}_{2}$ competes with $\mathrm{BH}_{4}$ for $\mathrm{NOS}$ but does not act as a cofactor, thereby fostering the uncoupling of NOS [32] and further exacerbating NOS dysfunction. Excess superoxide production previously reported in hph-1 mice [7] and oxidation of $\mathrm{BH}_{4}$ likely impaired its effect on HPV in heterozygous and hph-1 mice. The addition of MnTMPyP to the perfusate prior to the hypoxic challenge enhanced the vasodilatory effect of $\mathrm{BH}_{4}$ in all WT, heterozygous and hph-1 mice. These data are consistent with the observations of FARROW et al. [33], that recombinant human superoxide dismutase treatment increased eNOS activity and expression, elevated $\mathrm{BH}_{4}$ levels, decreased oxidative stress and induced pulmonary vasodilation in the persistent pulmonary hypertension model of neonatal lambs.

A limitation of this study is the lack of direct biochemical measurement of superoxide and $\mathrm{H}_{2} \mathrm{O}_{2}$ levels coincident with the biochemical manipulations. There are sufficient data from published work to support the interpretations made $[24,28$, 33-35]. The absence of these measurements, however, does not permit comment on the extent to which pharmacological manipulation of each contributes to the effects observed.

In summary, $\mathrm{BH}_{4}$ participates in the regulation of the pulmonary vascular response to hypoxia through the generation of $\mathrm{NO}$ and superoxide, and consequently the formation of hydrogen peroxide and peroxynitrite (fig. 5). The net effect of pharmacological supplementation with $\mathrm{BH}_{4}$ is to inhibit the pressor response. The effect is attenuated in the presence of oxidative stress and combining $\mathrm{BH}_{4}$ with an antioxidant strategy (for example, a superoxide dismutase mimetic) augments the efficacy of $\mathrm{BH}_{4}$ treatment. Pharmacological administration of $\mathrm{BH}_{4}$ may have therapeutic potential in pulmonary hypertension and warrants further investigation.

\section{SUPPORT STATEMENT}

This work is supported by the British Heart Foundation (London, UK), BioMarin Pharmaceuticals, Inc. (Novato, CA, USA) and PULMOTENSION (European Commission under the 6th Framework Programme, contract numbers LSHM-CT-2005-018725, Brussels, Belgium).

\section{STATEMENT OF INTEREST}

A statement of interest for M.R. Wilkins and for the study itself can be found at www.erj.ersjournals.com/misc/statements.dtl

\section{ACKNOWLEDGEMENTS}

We thank A. Hobbs (University College London, London, UK) for nitrate/nitrite measurement.

\section{REFERENCES}

1 Zhao L, Mason NA, Morrell NW, et al. Sildenafil inhibits hypoxiainduced pulmonary hypertension. Circulation 2001; 104: 424-428.

2 Cremona G, Wood AM, Hall LW, et al. Effect of inhibitors of nitric oxide release and action on vascular tone in isolated lungs of pig, sheep, dog and man. J Physiol 1994; 481: 185-195.

3 Champion HC, Bivalacqua TJ, Greenberg SS, et al. Adenoviral gene transfer of endothelial nitric-oxide synthase (eNOS) partially restores normal pulmonary arterial pressure in eNOS-deficient mice. Proc Natl Acad Sci USA 2002; 99: 13248-13253.

4 Vasquez-Vivar J, Kalyanaraman B, Martasek P, et al. Superoxide generation by endothelial nitric oxide synthase: the influence of cofactors. Proc Natl Acad Sci USA 1998; 95: 9220-9225.
5 Khoo JP, Nicoli T, Alp NJ, et al. Congenic mapping and genotyping of the tetrahydrobiopterin-deficient hph-1 mouse. Mol Genet Metab 2004; 82: 251-254.

6 Nandi M, Miller A, Stidwill R, et al. Pulmonary hypertension in a GTP-cyclohydrolase 1-deficient mouse. Circulation 2005; 111 2086-2090.

7 Khoo JP, Zhao L, Alp NJ, et al. Pivotal role for endothelial tetrahydrobiopterin in pulmonary hypertension. Circulation 2005; 111: 2126-2133.

8 Fagan KA, Fouty BW, Tyler RC, et al. The pulmonary circulation of homozygous or heterozygous eNOS-null mice is hyperresponsive to mild hypoxia. J Clin Invest 1999; 103: 291-299.

9 Cai H, Harrison DG. Endothelial dysfunction in cardiovascular diseases: the role of oxidant stress. Circ Res 2000; 87: 840-844.

10 Cracowski JL, Cracowski C, Bessard G, et al. Increased lipid peroxidation in patients with pulmonary hypertension. Am J Respir Crit Care Med 2001; 164: 1038-1042.

11 Robbins IM, Morrow JD, Christman BW. Oxidant stress but not thromboxane decreases with epoprostenol therapy. Free Radic Biol Med 2005; 38: 568-574.

12 Bowers R, Cool C, Murphy RC, et al. Oxidative stress in severe pulmonary hypertension. Am J Respir Crit Care Med 2004; 169: 764-769.

13 Kuzkaya N, Weissmann N, Harrison DG, et al. Interactions of peroxynitrite, tetrahydrobiopterin, ascorbic acid, and thiols: implications for uncoupling endothelial nitric-oxide synthase. J Biol Chem 2003; 278: 22546-22554.

14 Landmesser U, Dikalov S, Price SR, et al. Oxidation of tetrahydrobiopterin leads to uncoupling of endothelial cell nitric oxide synthase in hypertension. J Clin Invest 2003; 111: 1201-1209.

15 Laursen JB, Somers M, Kurz S, et al. Endothelial regulation of vasomotion in apoE-deficient mice: implications for interactions between peroxynitrite and tetrahydrobiopterin. Circulation 2001; 103: $1282-1288$

16 Garry A, Edwards DH, Fallis IF, et al. Ascorbic acid and tetrahydrobiopterin potentiate the EDHF phenomenon by generating hydrogen peroxide. Cardiovasc Res 2009; 84: 218-226.

17 Kirsch M, Korth HG, Stenert V, et al. The autoxidation of tetrahydrobiopterin revisited. Proof of superoxide formation from reaction of tetrahydrobiopterin with molecular oxygen. J Biol Chem 2003; 278: 24481-24490.

18 Zhao L, Brown LA, Owji AA, et al. Adrenomedullin activity in chronically hypoxic rat lungs. Am J Physiol 1996; 271: H622-H629.

19 Dias-Junior CA, Gladwin MT, Tanus-Santos JE. Low-dose intravenous nitrite improves hemodynamics in a canine model of acute pulmonary thromboembolism. Free Radic Biol Med 2006; 41: 1764-1770.

20 Voelkel NF. Mechanisms of hypoxic pulmonary vasoconstriction. Am Rev Respir Dis 1986; 133: 1186-1195.

21 Archer SL, Tolins JP, Raij L, et al. Hypoxic pulmonary vasoconstriction is enhanced by inhibition of the synthesis of an endothelium derived relaxing factor. Biochem Biophys Res Commun 1989; 164: 1198-1205.

22 Tzeng E, Billiar TR, Robbins PD, et al. Expression of human inducible nitric oxide synthase in a tetrahydrobiopterin $\left(\mathrm{H}_{4} \mathrm{~B}\right)$ deficient cell line: $\mathrm{H}_{4} \mathrm{~B}$ promotes assembly of enzyme subunits into an active dimer. Proc Natl Acad Sci USA 1995; 92: 11771-11775.

23 Capettini LS, Cortes SF, Gomes MA, et al. Neuronal nitric oxide synthase-derived hydrogen peroxide is a major endotheliumdependent relaxing factor. Am J Physiol Heart Circ Physiol 2008; 295: H2503-H2511.

24 Drouin A, Thorin-Trescases N, Hamel E, et al. Endothelial nitric oxide synthase activation leads to dilatory $\mathrm{H}_{2} \mathrm{O}_{2}$ production in mouse cerebral arteries. Cardiovasc Res 2007; 73: 73-81.

25 Milstien S, Katusic Z. Oxidation of tetrahydrobiopterin by peroxynitrite: implications for vascular endothelial function. Biochem Biophys Res Commun 1999; 263: 681-684. 
26 Mayahi L, Heales S, Owen D, et al. (6R)-5,6,7,8-Tetrahydro-Lbiopterin and its stereoisomer prevent ischemia reperfusion injury in human forearm. Arterioscler Thromb Vasc Biol 2007; 27: 1334-1339.

27 Takaki A, Morikawa K, Tsutsui M, et al. Crucial role of nitric oxide synthases system in endothelium-dependent hyperpolarization in mice. J Exp Med 2008; 205: 2053-2063.

28 Cosentino F, Barker JE, Brand MP, et al. Reactive oxygen species mediate endothelium-dependent relaxations in tetrahydrobiopterindeficient mice. Arterioscler Thromb Vasc Biol 2001; 21: 496-502.

29 Iesaki T, Gupte SA, Kaminski PM, et al. Inhibition of guanylate cyclase stimulation by $\mathrm{NO}$ and bovine arterial relaxation to peroxynitrite and $\mathrm{H}_{2} \mathrm{O}_{2}$. Am J Physiol 1999; 277: H978-H985.

30 Iida Y, Katusic ZS. Mechanisms of cerebral arterial relaxations to hydrogen peroxide. Stroke 2000; 31: 2224-2230.

31 Kuzkaya N, Weissmann N, Harrison DG, et al. Interactions of peroxynitrite, tetrahydrobiopterin, ascorbic acid, and thiols: implications for uncoupling endothelial nitric-oxide synthase. J Biol Chem 2003; 278: 22546-22554.

32 Crabtree MJ, Smith CL, Lam G, et al. Ratio of 5,6,7,8-tetrahydrobiopterin to 7,8-dihydrobiopterin in endothelial cells determines glucose-elicited changes in $\mathrm{NO}$ versus superoxide production by eNOS. Am J Physiol Heart Circ Physiol 2008; 294: H1530-H1540.

33 Farrow KN, Lakshminrusimha S, Reda WJ, et al. Superoxide dismutase restores eNOS expression and function in resistance pulmonary arteries from neonatal lambs with persistent pulmonary hypertension. Am J Physiol Lung Cell Mol Physiol 2008; 295: L979-L987.

34 Burke TM, Wolin MS. Hydrogen peroxide elicits pulmonary arterial relaxation and guanylate cyclase activation. Am J Physiol 1987; 252: H721-H732.

35 Sommer N, Dietrich A, Schermuly RT, et al. Regulation of hypoxic pulmonary vasoconstriction: basic mechanisms. Eur Respir J 2008; 32: 1639-1651. 